\title{
The Role of Schools Co-Operative in Cultivating Entrepreneurship Culture and Mind among Chinese Students
}

\author{
Osman jusoh \\ Senior Lecturer, Department of Business Management /Entrepreneurships \\ Faculty of Business and Economic, Education University of Sultan Idris \\ 35900 TanjongMalim, Perak, Malaysia \\ osman@fpe.upsi.edu.my
}

\begin{abstract}
Entrepreneurship is very important in the development of human capital and the development of the country. The objective of this study is to explore the role played by the Co-operativeactivities in school in cultivating entrepreneurship culture among Chinese students. Eight dimensions of entrepreneurial tendencies were selected and divided into external and internal factors. The external factors included future orientation, social network and the external environment. The internal factors are motivation, creativity and innovation, self-esteem, locus of controland lastly risk-taking. According to McClelland'sTheory of Motivation Achievement, individuals withhigh potentialenergyandhowthisenergyis releasedand developeddependon the individuals' strengthor motivationand also the opportunities available. A total of one hundred students from a Chinese national type secondary schools in the District of Manjung, Perak were randomly selected for this study. They were studying in Form 4 and Form 5 who might or might not involve in the school co-operative activities. The questionnaire used was tested with the Cronbach Alpha and the reliability valued was 0.931 . The results showed that the school co-operative activities did not play a significant role in instilling entrepreneurship among Chinese students $(r=-0029, p=0.771) p<0.05$. Despite coming from a business family, the students did not show any tendency to engage in entrepreneurship which was shown by thet- test resultst $(98, p=0.511)=-0.660$ and therefore $p>0.05$. Besides, the studies also showed that there are no correlation between the family sizes and thehierrachy of students in the family with entrepreneurship.As a suggestion, the school cooperativesociety should develop students internal locus of control through activitiesthat could strengthenandenrich them in order to build the personality ofa goodentrepreneur. Entrepreneurial PolicyDevelopment inHigher Education Institutionsof Malaysia should alsoconsiderits implementationat the school level. With thecontinuitybetweenschoolandhigher education institutions, it is hoped thatthe number ofsuccessful entrepreneursamong students are enhanced.
\end{abstract}

Keywords: Entrepreneur, external factors, internal factors, culture Chinese students

\section{INTRODUCTION}

Entrepreneurship is important to the world today. It is a catalyst for change and growth in a country's economy. This is in line with the opinion of Vinten et al., (2004); Aini Hayati et al., (2005), who stated the field of entrepreneurship is very important in the economic development of a country. Kamarulzaman Ismail and Ab Amaludin. Rahman (2009), said that individual entrepreneurship culture can be nurtured and educated. Yusof Boon and Sapiah Bohari (2010), had the opinion that school is the most appropriate starting point for students to take the opportunity to nurture their interest in entrepreneurship. This is in line with the personality of the students who show interest operating in the co-operative work in school.

Various attempts have been made by the government to develop the objectives of the school co-operative. SKM is always making sure that the schoolco-operatives can achieve the objectives listed. Among the objectives are to;

- $\quad$ Develop the practice of thrift and self-reliance among the students.

- $\quad$ Sowing the attributes and elements of democracy among the younger generation.

- $\quad$ Encourage an attitude of cooperation and mutual help among each other.

- $\quad$ Produce generation leaders of the intellectual caliber and vision.

- $\quad$ Provide supplies and services needed by the student. 


\section{PROBLEM STATEMENT}

In the olden days, when mentioned only entrepreneurship, many would associate it with the Chinese community. No doubt at that time, Chinese people had been involved in the business world and they were marked as leader in this fieldwhereby the locals were still working as fishermen, farmers and rubber tappers. According to Noor Zalika (2013), such conditions caused a notable economic gap between the races at that time due to the British policy of 'divide and rule' However, this scenario is no longer applicable today.

In this modern era, the Malays and other races are more advanced and competitive in the field of entrepreneurship. The question that arises is whether the Chinese children are no longer interested or theylack support and encouragement from their parents to start their own business. Through the observation done these days, Chineseparents with business background had given less encouragement to their children to venture into business.

Chin Yee Whah (2003), explains the influence of family background as a contribution in influencing the success of an entrepreneur. Continuing their parents' business have a positive impact on anentrepreneur because parents can help to influencepatron suppliers and buyers.According to Hisrich (2000), entrepreneurial career is influenced by the parental occupational background of an entrepreneur and the family plays a role in promoting entrepreneurship as a career. This is supported by Nor Aishah (2002) who found that there is a fairly strong correlation between family career and career choices of their children.

\section{RESEARCH OBJECTIVES}

Specifically, this research is conducted to achieve the following objectives:

i. To identifyif Chinese student participation in co-operative activities enhances entrepreneurship.

ii. To identify the differences in family backgroundtowards influencing entrepreneurship.

iii. To identifythe differences in attitude towards entrepreneurship among Chinese students pertaining to gender.

iv. To identify the relationship of family size with entrepreneurship involvement.

v. To identify the student hierrachy in the family with entrepreneurship indulgence.

\section{RESEARCH QUESTIONS}

This research is conducted to answer the following questions:

i. AreChinesestudents' participationinco-operativeactivities a factor thatenhancesentrepreneurship?

ii. Are there anyrelationship between Chinese students backgroundwithentrepreneurship?

iii. $\quad$ Are there any differences towards entrepreneurship based on gender of students?

iv. Are there any relationshipbetween thefamilysize with entrepreneurship?

v. Are there any relationship between the student hierrachy in the family with their entrepreneurship?

\section{RESEARCH HYPOTHESES}

The nullhypotheseswere formedto answer the research questions. Among them are:

$\mathrm{H}_{01}$ : There is no significant relationship between Chinese hierrachystudent participationinco-operativeactivities withentrepreneurship.

Ho2: $\quad$ There is no significant differences between family backgroundamong Chinese studentswithentrepreneurship.

$\mathrm{H}_{03}$ : There is no significant differencesof interest inentrepreneurshipamongChinese studentsby gender.

$\mathrm{H}_{04}$ : There is no significant relationship betweenfamily size among Chinese studentswith entrepreneurship

$\mathrm{H}_{05}$ : There is no significant relationship between the students hierrachy in the family with entrepreneurship. 


\section{LITERATURE REVIEW}

History has shownthat countries withmany entrepreneursareforging aheadintheir economicdevelopment. A country that is progressing or regressing is highly dependent onthe dynamics of the entrepreneursand theirvision to achieve. According to Nabi\&Holden(2008) andNorasmah\&Halimah(2007), a career in thefield of entrepreneurshipis one ofthe best jobsthat can be pursuedby individuals. This is supported inNorash\&Salmah(2011) researchwhich stated that an individual shouldthinkas the creator ofa job instead of finding a job.In this regard, the government has initiated the establishment ofthe Ministry ofEntrepreneur Developmentin 1995 as abodythatmanaged the development ofentrepreneurs. Throughthisministry, the government has establishedvarious programmes to improve the skillsof entrepreneurshipfor entrepreneurs in order to compete in this era of globalization.

McClelland(1978);AbdulRahman(1997), says thatindividualmotivationwillincrease if, first and foremost, one ismotivated. Secondly,heunderstandsthe elements ofmotivation. Thirdly, he is actively involvedinthe effort . Motivation is a set ofprocesses thatprovide energy to theperson's behaviorandbehavioralgoalsthatleadtoachieving the goal. A motivatedpersonwillmakea positive choicetodo something, because he knows what thisactionmeans to him, therefore can also satisfyhis needs. In addition,McClelland(1978) alsostressed thatthemotivated individuals has high achievement. This is becausetheseindividualshave a desire toovercome obstacles andhasslesin order toachievesomething worthy. Thus, TheTheoryOf MotivationAchievement isgivinghopeforsuccessandfear offailureis embeddedin the psycheof the individual.

Entrepreneurial culture ispositive propertiesownedbyan individual such ascourage,determinationandenthusiasm. The propertiescan alsobecapitalandassetsfor tradingandconvincing others. Entrepreneurial cultureshould be nurturedstartingfrom primary schoolthroughentrepreneurshipprogrammesconducted bystudentsandsupervised byexperiencedteachers. This culturealsoneed to be nurturedata higherlevel of educationby offeringcourses, programmes, seminarsoractivitiesthat encouragethem to venture intoentrepreneurship.Cultureisimportantand needs to benurturedcontinuously so that interests andsolid foundationcan be achieved.

\section{RESEARCH METHODOLOGY}

In this study, the researcherchosethe survey methodofusingquestionnaires. This questionnairehas been redesigned andadaptedfrom a study conductedbyKhalid(2013). The questionnairecontains55 itemsandis divided intotwo parts.PartA consists of 10items related tostudentdemographic. PartB consistsof 45 itemsrelated tomotivation, creativityandinnovation, self-esteem,locus of control, the willingness to take risks,futureorientation, social networking, the environment and involvementin co-operative society inschool.

There aretwomaintypes of datausedin this study. Premierdata isobtainedfromrespondentsthrough questionnairewhilesecondarydata isobtainedthroughliterature review. Quantitativemethodwas chosen because itwasmore convenient and easiertoobtaindataandabesides itfacilitatesresearcher toanalyze data.

\section{RESULTS}

Table1 shows themean andstandard deviationsforthe variables which influence entrepreneurship. Of the eightvariables studied, the meanfor thecreativityandinnovation is 3.94 , the mean for futureorientationis 3.97 andfor risk taking is 3.74 . All three ofthesevariablesshoweda highlevel ofmean.Moderatemean levelare shown by motivationwith mean 3.62 , social networking3:58, the external environment3:59, self confident 3.48andlocus of control3:37.

Table 1 MeanAnd Standard Deviation For Variables Which Influence Entrepreneur

\begin{tabular}{llll}
\hline Item & Mean & SD & $N$ \\
\hline
\end{tabular}




$\begin{array}{lllr}\text { Creativity and innovation } & 3.94 & 0.55 & 100 \\ \text { Self confident } & 3.48 & 0.49 & 100 \\ \text { Locus of control } & 3.37 & 0.5 & 100 \\ \text { Risk taking } & 3.74 & 0.54 & 100 \\ \text { Future orientation } & 3.97 & 0.57 & 100 \\ \text { Social networking } & 3.58 & 0.62 & 100 \\ \text { External environment } & 3.59 & 0.56 & 100\end{array}$

Note: lowlevel at 1-2.33,moderate level at 2.34-

3.67High level at , 3.68-5.00

Table 2 shows the correlationbetweenstudent participationinco-operativewithentrepreneurship.

\begin{tabular}{|c|c|c|c|c|}
\hline & & $\begin{array}{l}\text { Co-operative } \\
\text { activities }\end{array}$ & Entrepreneurship & Working in school co-op \\
\hline \multirow[t]{3}{*}{ Co-operative activities } & $\begin{array}{l}\text { Pearson } \\
\text { Correlation }\end{array}$ & 1.0 & $.506^{\star \star}$ & $-0.233^{\star}$ \\
\hline & Sig. ( 2 -tailed) & & 0 & 0.02 \\
\hline & N & 100.0 & 100 & 100 \\
\hline \multirow[t]{3}{*}{ Entrepreneurship } & $\begin{array}{l}\text { Pearson } \\
\text { Correlation }\end{array}$ & $.506^{* *}$ & 1 & 0.029 \\
\hline & Sig. ( 2 -tailed) & 0.0 & & 0.771 \\
\hline & N & 100.0 & 100 & 100 \\
\hline \multirow[t]{3}{*}{$\begin{array}{l}\text { Working in schoolco- } \\
\text { operative }\end{array}$} & $\begin{array}{l}\text { Pearson } \\
\text { Correlation }\end{array}$ & $-0.233^{*}$ & 0.029 & 1 \\
\hline & Sig. ( 2 -tailed) & 0.2 & 0.771 & \\
\hline & $\mathrm{N}$ & 100.0 & 100 & 100 \\
\hline
\end{tabular}

Nota : * correlation significant at 0.05 ( 2 tailed)

${ }^{* *}$ correlation significant at 0.01 ( 2 tailed)

In the first research question, the study examined whether the participation of Chinese students in school co-operative can influence their tendency in entrepreneurship. Here the null hypothesis has been formed to examine the relationship between the two variables. The result is shown in Table 2. Pearson correlation tests conducted showed no significant relationships between the Chinese students who were involved in the school co-operative and entrepreneurship. The test results recorded $(r=-0.029, p=0.771) p<0.05$. This has indicated that the school co-operatives as a platform for the students to familiarize with the entrepreneurship world has not play an effective role among Chinese students. This is because they can get experience in entrepreneurship either by their family background or working with others. Most Chinese students gain experience in entrepreneurship through retail shops, food stalls and supermarket stores that are abundant in this area. In addition, the activities carried out by the schoolco-operative in the study are limited to the stationary only. This has limited their exposure to entrepreneurship. Students are not involved in the transaction to buy stock, setting the selling price of goods and management experience like accounting. These alone showed that the experiences received by students is rather inadequate. 
Table 3 T-Test between Family Backgroundand Inclination toward Entrepreneurship

\begin{tabular}{lccc}
\hline variable & $\mathrm{t}$ & $\mathrm{df}$ & $\mathrm{Sig}(2$ taile $)$ \\
\hline Entrepreneurship & & & \\
& -0.66 & 98 & 0.511 \\
\hline
\end{tabular}

The second question is whether the family background influence entrepreneurial among Chinese students. Here, the researcher divided the parents occupation into two categories: business and non-business. The results show that only $30 \%$ of respondents had business background and $70 \%$ of the parents work for the government, private sector and others. The t tests results showed $t(98, p=0511)=-0.660$ and the value of $p>0.05$. So it may be concluded that there is no significant influence on entrepreneurship in terms of differences in the parental occupational. The results are shown in Table 3. This also implies that parents are not necessarily encouraging the children to follow in their footsteps. The findings are consistent with the problems posed by the researcher studies in which researcher found that the Chinese parents nowadays do not encourage their children to be active in the business. The reason giveninclude the high risks involved and the benefits derived are not so lucrative. Working as an entrepreneur also requires high resilience and selfconfidence inorder to continue to be active in this field. Although the study also found that Chinese students dare to take risks, but they do not want to venture into entrepreneurship because they want to live in comfort without working for long hours. In Manjung District, small businesses have to compete with large supermarkets such as AEON, Giant, Tesco, Billion, The Store, Econ Save and Rapid Supermarket. Their existence has resulted in small businesses gain decreases and difficult to continue their business.

Table 4T-TestForEntrepreneurshipTendencyBased onGender

\begin{tabular}{llll}
\hline variable & $\mathrm{t}$ & $\mathrm{df}$ & $\operatorname{Sig}(2$ tailed $)$ \\
\hline Entrepreneurship & 0.633 & 98 & 0.528
\end{tabular}

Nexttoanswer the question ofwhether theChinesestudents' genderhas a significant

relationshipwithentrepreneurialtendencies, researchersrandomly selectedChinese studentsin terms ofgenderdistribution. Researchers found that $51 \%$ of respondents werefemale studentsand $49 \%$ of them aremale students. Thus, the distributionof respondents are considered fair to testthe questionabove. The researcher also conducteda t-teston thedependent variable,entrepreneurandindependent variables of genderandthe findingsare listed in Table4.

T-testsconducted showed differences in genderamong Chinese students do not play asignificantroleinentrepreneurship. The results ofthe t-testist $(98, p=0528)=0633$ wherep $<0.05$. Thusgenderis nota determining factorforentrepreneurshipamong Chinese students. The finding is consistent with the research conducted by Rosli (2013) who found no significant differences between mean scores of entrepreneurial tendencies based on gender. This study is also consistent with Davidson (1995) who found that gender has little or no influence on entrepreneurship.

Table 5 Correlation BetweenFamily Size And Entrepreneurship Tendency

\begin{tabular}{llll}
\hline & & Family sizes & Entrepreneurship \\
\hline Family sizes & Pearson Correlation & 1 & .152 \\
& Sig. (2-tailed) & & .131 \\
& $\mathrm{~N}$ & 100 & 100 \\
Entrepreneurship & Pearson Correlation & .152 & 1 \\
& Sig. (2-tailed) & $.0 \bullet$ &
\end{tabular}


Table 6 Correlation BetweenStudentHierrachyIn The FamilyWithEntrepreneurial Tendencies

\section{Student hierrachy in the family}

Entrepreneurship

\begin{tabular}{llll}
\hline Entrepreneurship & Pearson Correlation & 1 & -.034 \\
& Sig. (2-tailed) & & .740 \\
& $\mathrm{~N}$ & 100 & 100 \\
Student hierrachy in the & Pearson Correlation & -.034 & 1 \\
family & Sig. (2-tailed) & .740 & 100 \\
\hline
\end{tabular}

To answer the fourth question, the researcher has used Pearson correlation. Here the question is whether the size of the family played a significant role in entrepreneurship. The null hypothesis was rejected because the results show that ( $r=0: 15, p=0.13), p>0.05$. From the findings of this study, it can be concluded that the size of Chinese families has no significant correlation with entrepreneurship . In ancient times, the size of the family is important as parents need help from their children to keep the business going. But now the situation does not exist anymore because many traders are hiring foreigners from Pakistan, Bangladesh, Vietnam and others.

This study differs fromHisan (2007) that indicates the size of the family influence entrepreneurial among Malay students in LamborKiri. The same opinion is also given by Sodri( 2002 ) which statedfamily environment influence the children attitude.

Finally, the question presented is whether there is a relationship between the students hierrachyin the families withentrepreneuship. Does the eldest more interested in doing business compared with the other children. Referring to the findings in Table 6 , Pearson correlation $r=-0: 34, p=0.74$ showed that the two variables have no significant relationship because the value of $p>0.05$. The results also show that many Chinese families have fewer children and they are less likely to distinguish affection for their children, teach them to be more independent and cultivate positive attitude to all their children regardless of their hireaklyin the family. This finding is in line with Chin Yee Wah(2003) who stated that the role of parents in bringing up and educating their children is important for the children character building. A study conducted by Hisan( 2007 ) on the Malay students in LamborKiri , Perak reported that the eldest son showed greater devotion to duty, initiative and confident in a job compared with the middle and youngest child.

\section{SUGGESTION AND CONCLUSION}

The studywas aneffort toimprovethe school'sco-operativeroleinfostering entrepreneurship culture amongChinese students. The study is based onChinesestudents, co-operativeteachers, the schools involved andthe Co-operative Commission ofMalaysia. Severalsuggestions have been proposedto improve the co-operative role and also as a guide for future studies.

Based on the results, the variableswith the lowestmean valueis thelocus of control. Therefore it isproposed thatlocus of controlshould be cultivated and strengthenedamongChinese students. This is also true, based on the report submittedbyacademicians with entrepreneurialmastery likeMcClelland, Litttunen, Rotter, andSchumpter. Intheir research, they found thatlocus of controlis a major factorof personalityformation ofa goodentrepreneur. Rosli(2013) has arguedthatindividualswithinternallocus of control,self-reliance, risk-taking, self-confidence, self-controlhave the ability and desire tomaterialize their ideas. Thus theChinese students haveto be exposedto activitiesthat could strengthenandenrich their experiences in order to become goodentrepreneurs. 
School Co-operatives are more focused on business activities such as selling stationery items, exercise books, sports tshirt, and other small items. This function can actually be expanded to the sale of daily necessities such as rice, soap powder, cooking oil, dry stuffs such as dry noodle, beans and others. By selling grocery items, it will not only increase its income but alsoprovide services to the surrounding community. In addition, school co-operatives are also encouraged to host the Co-operativeTourism to enable the members of the society to gain knowledge pertaining to tourism. Datuk Haji Abdul Fattah (2014) from ANGKASA has called on the students and teachers to venture into tourism activities. This could give the students a chance to learn the management entailed in tour packages besides helping the school co-operatives to generate profits.

In linewiththe government's goalto producequality human capital who are innovative and creatives, totransformthe nation's economy, educationand other programmes andactivitiesof entrepreneurial cultureamonguniversity studentsshouldalso be extendedto studentsinschool. A moreorganizedand integrated step should be taken bythe Ministry of Educationin providingprogrammes to enhanceentrepreneurshipandinfrastructureand a conducive environmenttothe studentswho reallyhave a passionanddesireto become an entrepreneur. EntrepreneurialDevelopment PolicyinHigher Education Institutionsshould alsoconsiderits implementationat the school level. With thecontinuitybetweenschoolandhigher education institutions, it is hoped thatthe number ofsuccessful entrepreneurswould increase.

The processof entrepreneurial cultureis along-term processandrequirescontinuous effort. In our countrythe processof entrepreneurial culturehas become amajor focus, thereforeithastostart early when the students are still in primaryand secondary schools. Consequently it should be expanded tostudentsinhigher education irrelevant whether they belong to the private or public institutions. Given the importance of establishingentrepreneurial culture, the school cooperativehas taken the initiative to expose the students to the business worldas earlyas possible.

Fromthis research,moreeffortshould be takentostrengthen theschool co-operatives so that it canfunction properly. School co-operativesshouldtakemore initiativesand grab the opportunities providedbythe Co-operative Commission of Malaysia to conduct appropriate programmes for its members. Co-operative activities should no longer limited to retail sales only.It should take up creative and innovative steps to participate as hosts in the Tourism Co-operative Young Entrepreneur Programme and other projects too pen the eyes andminds of the students.

Finally, all students should seize the opportunity to gain the competitive andentrepreneurialknowledgeprovidedat the schoolthroughco-operativeorthroughthe subjects taught. In doing so,theywill be better preparedto face the futurewithhopetobecome a successful entrepreneur.

\section{REFERENCES}

[1] Ab. Aziz Yusof (2013). StrategiUsahawanCemerlang. Kuala Lumpur: Utusan Publication \& Distributor Sdn Bhd.

[2] Ab. Aziz Yusof (2003). PrinsipKeusahawanan. Kuala Lumpur, Prentice Hall.

[3] Ab. Aziz Yusof(2010).Usahawan\&Keusahawanan. Kuala Lumpur: Scholarmind Publishing.

[4] AiniHayatiMohamad, Abu BakarHamed, Norsiah Mat (1999). WanitaMenujuke Era Keusahawanan: MemahamiAktivitiJaringanUsahanita, JurnalPengurusan, Vol 18: 109-129 UKM.

[5] AinonMohddan Abdullah Hassan ( 996). SeniBerfikirKreatif. Kuala Lumpur: Utusan Publication \& Distributor Sdn Bhd.

[6] Alias Baba (1992). StatistikPenyelidikandalamPendidikandanSains. Bangi: Penerbit UKM.

[7] ArmibtHjZainuddin (1997). PrestasiKoperasiSekolahDalamGerakanKoperasi. Kertas Seminar KoperasiSekolah: Cabaran\&ArahtujuAlaf Akan Datang.

[8] AsmawatibintiHashim (2002).

"PersepsiPelajarTerhadapPerananKoperasiSekolahDalamMembentukSifatKeusahawanan: SatuTinjauan di TigaBuahSekolah di PekanMerlimau, Melaka" ProjekSarjanaMuda. Tidakditerbitkan.

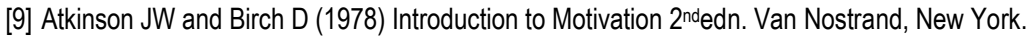

[10] AziziYahaya, ShahrinHashim, JamaludinRamli, Yosuf Boon dan Abdul Rahim Hamdan (2006). MenguasaiPenyelidikanDalamPendidikan. Kuala Lumpur: PTS Professional Publishing Sdn. Bhd. 
[11] Baharu bin Kemat (1994). OrientasiSikapKeusahawanan di KalanganPelajarPoliteknik di Malaysia, TesisSarjanaSainsPengurusan, Universiti Utara Malaysia.

[12] Bird J.B. (1989). Entrepreneurial Behavior. London, Scott, Foresman\& Company.

[13] Bird, Barbara \&MariannJelinek (1988). The Operation of Entrepreneur Intentions, Entrepreneurship Theory and Practice.

[14] BorjoyaiBardai (2000). KeusahawanandanPerniagaan. Kuala Lumpur: DewanBahasadanPustaka.

[15] Borland, C. (1974) Lokus of Control, Need for Achivement, and Entrepreneurship. Unpublished doctoral dissertation, University of Texas at Austin. Boston:PWS-Kent

[16] Carsud, A.L. \&Olm, K.W. (1996). The Success Of Male And Female Entrepreneurs: A Comparative Analysis In Managing Take Off In Fast Growth Firms. New York: Praeger Publisher.

[17] Chek Pit Chow (2002). Ciri-ciriKeusahawanan di KalanganPelajarSekolahMenengah di Wilayah Persekutuan. TesisSarjanaPendidikan, Bangi: UniversitiKebangsaan Malaysia.

[18] Choo, S \& Wong, M. (2006). Entrepreneurial Intention: Triggers and Barriers to New Venture Creations In Singapore. Singapore Management Review.

[19] Chua, Y.P. (2006). KaedahdanStatistikPenyelidikanBuku 1. Kuala Lumpur: McGraw-Hill Education.

[20] Craint. J.M (1996). The Proactive Personalty Scales As S Predictor Of Entrepreneural Intensions, Journal Of Small Business Management.

[21] Cunningham, J.B. \&Lischeron, J (1991). Definition Entrepreneurship. Journal of Small Business Management.

[22] De Bono (1975) Pemikiran Lateral. Terjemahan. Kuala Lumpur. Golden Books CenterSdn Bhd.

[23] Dollinger, M.J. (1995) Entrepreneurship; Strategies and Resources. Illinois: Irwin.

[24] Doughlas, E.J., \& Shepherd, D. A. (2002). Self -Employment as a Career Choice: Attitudes, Entrepreneurial Intentions, and Utility Maximization. Entrepreneurship Theory and Practice.

[25] Drucker, P.F. (1985). "The Practice Of Entrepreneurship", Innovation and Entrepreneurship Practice and Principles, Harper \& Row, New York.

[26] Hayati Md. Salleh, Asha'ari Arshad, Ahmad FaizalShaarani, NorbilaKasmuri. (2008). GerakanKoperasi Di Malaysia. MaktabKerjasama Malaysia. Petaling Jaya.

[27] HisanMohd. Sudin (2007). OrientasiKeusahawanan Di KalanganPelajarSekolahMenengahLamborKiri Perak. DisertasiSarjanaPendidikan,UniversitiPendidikan Sultan Idris.

[28] Hisrich, R.D. \& M.P. Peters (2002). Entrepreneurship (fifth edition). New York, NY: McGrawa- Hill/ Irwin

[29] Hisrich, R.D. \& M.P. Peters (2008). Entrepreneurship ( $7^{\text {th }}$ edition). New York, NY: McGrawa- Hill/ Irwin

[30] Howell, D. C (1992). Statistical Methods For Psychology (3rdEd.). Boston:PWS-Kent

[31] Humam Bin Haji Mohamed. (1988). Entrepreneurial Development In Malaysia With Specific Reference To Training And Development Initiatives. Doctor Of Philosophy. University Of Stirling, London.

[32] Jain,S. (1993). Marketing planning \& strategy (4thEd.) Cincinnati,Ohio: SouthWestern Publishing Company.

[33] KamusDewanEdisiBaru.(2003).DewanBahasadanPustaka.KementerianPendidikanMalaysia:Kuala Lumpur.

[34] Khairuddin Khalil (2003). KeusahawananSebagaiKerjaya. EdisiKedua Kuala Lumpur :DewanBahasa Dan Pustaka.

[35] Khalina Khalid (2004). PerananKoperasiSekolahDalamMemupukBudayaKeusahawanan Di KalanganAnggotaAnggotanya. KertasProjekSarjana. UniversitiKebangsaan Malaysia.

[36] Kirzner, I (1979). Perception, Opportunity And Profit: Studieson Theory Of Entrepreneurs. Chicago: The University Of Chicago Press.

[37] Krueger, N.F. \&Carsrud, A.L. (1993). Entrepreneurial Intentions: Applying The Theory Of Planned Behavior. Entrepreneurship \& Regional Development.

[38] Kuratko, D.F. \&Hodgetts, R.M. (1992). Entrepreneurship, A Contemporary Approach. London:Dryden Press. 
[39] Mastor bin Hemdi (2003). SatuKajianTerhadapGerakanKoperasiSekolah Di Daerah Kuala Kangsar, Perak. TesisSarjanaPendidikdan. UKM.

[40] Mazlan bin Kamis (1997). KoperasiSekolahSebagaiPemupukKeusahawanan,Latihanllmiah, Universiti Utara Malaysia.

[41] Mc Burney, D. H. (2001). Research Methods (5thed). California.Wadsworth.

[42] McClelland, D.C. (1965). NH Achievement and Entrepreneurship: A Longitudinal Study. Journal of Personality and Social Physchology.

[43] McClelland, D.C. (1961). The Achieving Society. New York: Irvington Publisher Inc.

[44] Mery Coulter(2000). Entrepreneuship Involves Changing, Revolutionizing, Transforming, Introducting New Approach:Prentice Hall.

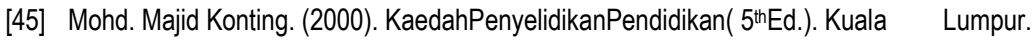

[46] Mohd. Najib Abdul Ghafar (2003). RekaBentukTinjauanSoalSelidikPendidikan. Skudai: UniversitiTeknologi Malaysia.

[47] Moorman, J.W. and Halloran, J.W. (1993). Entrepreneurship. Colorado: South Western Publishing Co.

[48] Natifahbt Abu Khairi. (2006). KecenderunganKeusahawanan Di KalanganPelajarJurusanPerakaunanKolejMetrikulasiPulau Pinang. Seminar PenyelidikanPendidikan Program Matrikulasi, KPM 2006.

[49] NawawiMohd Jan (1992). Kompetansikeusahawanan. AsasKeusahawanan. Pusat Pembangunan Usahawan Malaysia (MEDEC). Shah Alam. InstitutTeknologi Mara.

[50] Nor AishahBuang (2002). Asaskeusahawanan. Kuala Lumpur, FajarBakti.

[51] Nor Azizah Ismail (2000). AspirasiKeusahawanan Di KalanganPelajar-PelajarPerempuan Di SekolahMenengahTokJanggut, PasirPuteh, Kelantan. SatuTinjauan. TesisSarjanamuda Yang TidakDiterbitkan, Skudai :UniverisitiTeknologi Malaysia.

[52] Nor FadilaMohd Amin \&Dzufilszuralspaw (2011). Faktor-Faktor Yang MempengaruhiPemilihanBidangKeusahawananSebagaiKerjayaDalamKalanganPelajarPendidikanTeknikal Dan Vokasional. FakultiPendidikan,UniversitiTeknologi Malaysia,

[53] NorhattaMohamad (2003). Pengetahuan, Kemahiran Dan SikapDalamPerniagan Dan Keusahawanan DiKalanganPelajar-PelajarSekolahMenengah Di SekitarLembah Kelang. TesisSarjana Yang TidakDiterbitkan, Bangi: University Kebangsaan Malaysia.

[54] Noor Zalika (2013). Cabaran Dan HalanganMembangunkanUsahawan Bumiputera Berjaya http://azlanyusof.blogspot.com/2013/03/cabaran-dan- halangan-membangunkan.html

[55] Pallant, J. (2011). SPSS survival manual: A step-by-step guide to data analysis using SPSS. New South Wales: Allen \& Unwin.

[56] Ramayah, T. \&Harun, Z. (2005). Entrepreneurial Intention Among The Students Of University Sains Malaysia (USM). International Journal Of Management And Entrepreneurship.

[57] Ramlee Ismail, Jamal @ NordinYunus\& Hariri Kamis (2011). Analisis Data Dan PentafsiranDenganMenggunakan SPSS. Kuala Lumpur: Titisanllham.

[58] RamziahShamsuddin (2000). AmalanPendidikanKeusahawanan Di KalanganPelajarSemasaMenjalaniAktivitiKeusahawanan Di SekolahMenengahVokasional. TesisSarjanamuda Yang TidakDiterbitkan, Skudai: University Teknologi Malaysia.

[59] Rancangan Malaysia ke-sembilan, (2006-2010). Economic planning unit, Prime Minister's Department, Malaysia. Kuala Lumpur: PercetakanNasionalBerhad

[60] Roslan Ali. (2010, September 21)MindaUsahawan.JurnalUsahawan.

[61] RoslanHussin (2003). KecenderunganKeusahawanan Di KalanganPelajar-PelajarSekolahMenengah Agama Rakyat Di Negeri Perak. TesisFakultiPendidikan, UniversitiKebangsaan Malaysia.

[62] Rosli Khalid (2013). KecenderunganKeusahawananDalamKalangan Guru-Guru KoperasiSekolahMenengah Di Daerah Klang. KertasProjekSarjana. UniversitiPendidikan Sultan Idris. 
[63] SabriHj. Hussin (2002). PengenalanKepadaPerniagaan: MengurusPerniagaanDalamPerspektif Malaysia. Singapore: Thomson Learning

[64] Segal, G., Borgia, D., \&Schoenfeld, J. (2005). The motivation to become an entrepreneur. International Journal of Entrepreneurial behavior\& research, 11 (1).

[65] Sekaran, U. (2003). Research Methods For Business (4th ed.) Hoboken, New York: John Wiley \& Sons.

[66] Sekaran, U. 1992. Research Methods For Business: A Skill-Building Approach. (2nded.).New York: John Wiley \& Sons.

[67] ShahrinHashim 1 \&Noraini Radio (2011). Ciri Personality Keusahawanan. Journal Of Educational Management, Volume 4 December 2011, Pages 11/ ISSN: 2231-7341. FakultiPendidikan, UniversitiTeknologi Malaysia. http://eprints.utm.my/20951/1/Abstract EPRINT 96.pdf.

[68] ShamsuddinJusoh (2002). Persepsi Guru Dan PelajarSekolahMenengah Di Kelantan TerhadapPenerapanCiriCiriKeusahawanan. KertasProjekSarjana, UniverisitiKebangsaan Malaysia.

[69] Shapero,A\&Sokol,L (1982). The Social Dimensions Of Entrepreneurship.InC.A.Kent (Eds),Encyclopedia Of Entrepreneurship.Englewood Cliffs, New Jersey:Prentice-Hall,Inc.

[70] SharifahKamariahbt Syed Sofian (1996). The Identification Entrepreneurship Characteristic Among Secondary School Students In The District Of Hulu Langat, Selangor. TesisSarjana. University Putra Malaysia.

[71] SitiHawabinti Mohamed Idris (2009). KecenderunganKeusahawanan Di KalanganPelajarBidangKejuruteraan Di InstitusiPengajianTinggiAwam Di Kawasan Utara Semenanjung Malaysia. DesertasiSarjana. University Utara Malaysia.

[72] Stephens, P. R., Fry, F., Van Auken, H. (2006). The Influence Of Role Models On Entrepreneurial Intentions. Journal Of Developmental Entrepreneurship.

[73] Timmons, T.A., Smollen L.E.S. \&Dingee A.L.M. (1977).New Venture Creation:A Guide To Small Business Development. Ontorio: Richard D. Irwin.

[74] Timmons, T.A., Smollen L.E.S. \&Dingee A.L.M. (1977). New Venture Creation:

[75] Transforming, IntroductingNew Approach:Prentice Hall.

[76] Turner, D. (1997). Managing personal development. Petaling Jaya: Pelanduk Publications (M) Sdn. Bhd.

[77] UITM Entrepreneurship Study Group (2004). Fundamentals of Entrepreneurship Petaling Jaya: Prentice Hall Pearson Malaysia Sdn Bhd.

[78] Wan Liz Ozman Wan Omar \&Sulzari Mohamed (2002). MemperkasakanUsahawan: PanduanLengkapPengurusanPerniagaan Dan PenjanaanUsahawan. Kuala Lumpur: Utusan Publication \& Distributors Sdn Bhd.

[79] Wan Syukri Wan Drani (2004). PengaruhPersonalitiTerhadapKecenderunganKeusahawanan. Univerisiti Utara Malaysia.

[80] Wu Min Aun Dan Beatrix Vohrah (1990). Undang-UndangPerdagangan Malaysia. Petaling Jaya: Longman Malaysia Sdn. Bhd.

[81] Y.F Lay \& C. H. Khoo. (2009). PengenalanKepadaAnalisisData KomputerDengan SPSS 16.0 For Windows. Selangor: Venton Publishing (M) Sdn. Bhd.

[82] Yusof Bin Boon \&SapiahBintiBohari (2010). KesediaanUntukMenceburiBidangKeusahawanan Di KalanganPelajarPelajarBumiputeraTingkatanEmpat Di TigaBuahSekolahSekitarSkudai, Johor.

[83] ZaidatolAkmaliah Lope PihiedanHabibah Elias (1997b). Keusahawanan DanMotivasiDiri. Universiti Putra Malaysia.

[84] ZaharuddinYahya (1995). MemilihPerniagaan: KeArahPembentukanUsahawan Dan PengujudanPerniagaan Yang Berdayamaju. Kelantan: Al-Kafilah Enterprise. 